\title{
Detection of Tomato Ringspot Virus in Nectarine Trees Using ELISA and Transcribed RNA Probes
}

\author{
C.A. Powell \\ University of Florida, Institute of Food and Agricultural Sciences, \\ Agricultural Research and Education Center, Box 248, Fort Pierce, \\ FL 34954
}

\section{A. Hadidi}

National Plant Germplasm Quarantine Laboratory, Agricultural Research Service, U.S. Department of Agriculture, Building 01lA, Beltsville, MD 20705

\section{J.M. Halbrendt \\ Fruit Research Laboratory, Pennsylvania State University, Biglerville, PA 17307}

Additional index words. Prunus persica, stem-pitting disease, Malus domestica

\begin{abstract}
The ability of ${ }^{32} \mathrm{P}$-labeled transcribed cRNA probes to detect tomato ringspot virus (TmRSV) RNA in nucleic acid extracts from roots, bark, and leaves of nectarine (Prunus persica [L.] Batsch) trees with the Prunus stem-pitting disease was assessed and compared with detection of TmRSV antigen by enzyme-linked immunosorbent assay (ELISA) in the same tissues. Neither TmRSV-specific nucleic acid nor antigen was detected in nectarine leaf tissue. ELISA detected TmRSV antigen in root extracts from $71 \%$ of the diseased trees, while dot hybridization detected virus-specific nucleic acid in $18 \%$ of the same samples. However, ELISA detected TmRSV antigen in only 47\% of bark extracts; whereas TmRSV-specific nucleic acid was detected in $100 \%$ of the bark extracts from samples collected at or near the soil line. When nucleic acid extracts from bark were prepared from various locations on diseased trees and tested for TmRSV-specific nucleic acid by dot hybridization, there was an almost perfect correlation between the presence of stem-pitting symptoms and the detection of TmRSV nucleic acid. Detection of TmRSV RNA from the bark tissue of rootstock suckers from TmRSV-infected 'Delicious'/MM.IO6 apple (Malus $\times$ domestica Borkh.) trees was unsuccessful using dot hybridization. The viral RNA, however, was usually detected in either leaf or root tissue of these same trees.
\end{abstract}

Tomato ringspot virus (TmRSV), a member of the nepovirus group, causes economically important diseases in a variety of hosts, including fruit and ornamentals crops (Powell, 1984). Since many of these hosts are

Received for publication 7 Dec. 1990. Mention of a trade name, proprietary product, or specific equipment does not constitute a guarantee or warranty by the U.S. Department of Agriculture and does not imply approval to the exclusion of other products that may also be suitable. We thank Rosemary Walsh, Stephanie Tucker, Mike Derr, Shawnette Hayes, and Rodney Schaffer for excellent technical assistance. Agricultural Journal Series no. R-00639. The cost of publishing this paper was defrayed in part by the payment of page charges. Under postal regulations, this paper therefore must be hereby marked advertisement solely to indicate this fact. propagated vegetatively, the production and certification of TmRSV-free propagating stock is an important component of any control strategy. Thus, the development of reliable detection assays for TmRSV is a high research priority. This research has generally taken an immunological approach, involving the use of enzyme-linked immunosorbent assay (ELISA) procedures (Lister et al., 1980; Powell, 1984, 1987, 1990). These procedures have been of great value to certification programs and in epidemiological studies on TmRSV-induced diseases. However, the immunological approach can lead to falsenegative reactions because of low virus titer, uneven virus distribution (Bitterlin et al., 1984, 1988; Gonsalves, 1981), and strain variability (Bitterlin and Gonsalves, 1988) and false-positive reactions associated with normal plant components (Mink et al., 1985; Powell, 1984]. It would, therefore, be advantageous to be able to detect TmRSV by nucleic acid hybridization.

A portion of the TmRSV genome has been cloned and used to generate a cRNA probe that hybridizes specifically with RNA 2 of TmRSV (Hadidi and Powell, 1991). This report presents data comparing the efficiency of this probe with ELISA in detecting TmRSV in various tissues of nectarine trees. Detection of TmRSV in apple trees by a dot hybridization assay is also reported.

Leaf, bark, and root samples were collected from 17 nectarine trees with symptoms of the Prunus stem-pitting (PSP) disease from two Pennsylvania orchards in late summer; from five nectarine trees with symptoms of the same disease from the Fruit Research Laboratory, Biglerville, Pa., in spring; and from 11 virus-indexed nectarine trees from the Pennsylvania tree fruit repository. The symptomatic trees were known to contain TmRSV based on many previous ELISA tests in which they had tested positive for the virus at least once. Leaf samples consisted of four or five young leaves from different branches of these trees. Bark samples, unless otherwise indicated, were taken from below the soil line where symptoms were present. Root samples consisted of small feeder roots, no larger than $1 \mathrm{~mm}$, collected from the same side of the tree as the bark samples. The sample weight was $\approx 1 \mathrm{~g}$ and contained only living tissue. This sampling procedure was previously shown to work best for ELISA indexing of peach trees for TmRSV (C.A.P., unpublished data). Samples from six apple trees were collected in the spring from the leaves, bark, and root tissues of rootstock suckers from five 'Delicious'/ MM.106 apple trees with apple union necrosis and decline (AUND) from the Fruit Research Laboratory's orchard in Biglerville. Apple bark samples were collected from just above the soil line.

Each sample, on the day collected, was placed in a mortar and frozen by submersion in liquid nitrogen. The samples were triturated with a pestle while frozen and then thawed by adding $10 \mathrm{ml}$ of phosphate-buffered saline (PBS; 0.15 M sodium chloride, 0.015 M sodium phosphate, $\mathrm{pH}$ 7.4). Microtiter plates, precoated with antiserum to TmRSV-A (Powell and Derr, 1983), received $250 \mu \mathrm{l}$ of the extract from each sample in each of two wells. Eight milliliters of salt-saturated phenol and $8 \mathrm{ml}$ of chloroform were added to the remainder of the sap. This emulsion was centrifuged at $8000 \mathrm{rpm}$ for 10 rein, and the upper, aqueous layer was removed. Total cellular nucleic acids were precipitated from the aqueous layer with one- 
Table 1. Comparison of ELISA and dot blot hybridization for detecting TmRSV in nectarines with Prunus stem-pitting disease (PSP).

\begin{tabular}{lcc}
\hline \hline & \multicolumn{2}{c}{ No. positive/No. tested } \\
\cline { 2 - 3 } Sample $^{z}$ & ELISA & Hybridization \\
\hline PSP-leaf & $0 / 17$ & $0 / 17$ \\
PSP-bark & $8 / 17$ & $17 / 17$ \\
PSP-root & $12 / 17$ & $3 / 17$ \\
Healthy leaf & $0 / 10$ & $0 / 10$ \\
Healthy bark & $0 / 10$ & $0 / 10$ \\
Healthy root & $0 / 10$ & $0 / 10$ \\
\hline
\end{tabular}

2PSP samples were taken from 17 trees showing typical symptoms in the lower trunk and crown area. Healthy controls were from the Pennsylvania virus-indexed repository.

tenth volume of $3.0 \mathrm{~m}$ sodium acetate $(\mathrm{pH}$ 6.0 ), three volumes of $95 \%$ ethyl alcohol, and storage at $-20 \mathrm{C}$ overnight.

TmRSV antigen was detected by DAS ELISA as previously described (Clark and Adams, 1977; Powell, 1984). TmRSV RNA was detected by dot blot hybridization of total cellular nucleic acids with SP6-generated ${ }^{32} \mathrm{P}$-labeled cRNA probes, followed by autoradiography (Hadidi and Powell, 1991).

A comparison between ELISA and hybridization for detecting TmRSV infection of nectarine trees is shown in Table 1. TmRSV infection was not detected by either ELISA or hybridization in leaf extracts from nectarine trees with the PSP disease. ELISA detected TmRSV antigen in nectarine bark extracts of $47 \%$ of the diseased trees, and hybridization detected TmRSV RNA in 100\% of the extracts. ELISA detected TmRSV antigen in root extracts from $71 \%$ of the diseased trees, and hybridization detected TmRSV RNA in extracts from $18 \%$ of the trees. The extracts from leaves, bark, and roots of nectarine trees known to be free of TmRSV gave very low color (ELISA) or autoradiographic (hybridization) background. All tests were clearly positive or negative when read visually, and spectrophotometric or densitometric quantitation was unnecessary.

The results of a representative experiment comparing the presence of stem-pitting symptoms in young nectarine trees with the distribution of TmRSV-RNA are shown in Fig. 1. In general, extracts from bark removed from areas of the tree where stempitting symptoms occurred contained detect- able TmRSV RNA. Extracts from bark removed from above the stem-pitted region or from the opposite side of the trunk, where symptoms were absent, contained no detectable TmRSV RNA.

Nucleic acid extracts from leaves, bark, and roots of rootstock suckers of five 'Delicious'/MM.1O6 apple trees with AUND were compared with those from five nectarine trees with the PSP disease for the detection of TmRSV by dot hybridization assay (Table 2). Virus-specific RNA was detected in bark tissue extracts of all the symptomatic nectarine trees and in root tissue extracts of two of these trees but not in leaf extracts. Leaf or root tissue of four out of five symptomatic apple trees tested positive for TmRSV. The virus, however, was not detected in bark tissue of the apple trees.

The failure to detect TmRSV antigen and RNA in leaves of infected nectarine trees was expected. Numerous ELISA tests for TmRSV in peaches in Pennsylvania orchards over the last 10 years have rarely detected the virus above the soil line. The only time TmRSV was detected in leaves or flowers of field-grown peaches was during the first flush of growth in the early spring. This result could not be repeated in the same trees the following year (C.A.P. and M.A. Derr, unpublished data). In contrast, TmRSV could easily be detected in leaves of peach trees inoculated with TmRSV by nematodes and maintained in the greenhouse. The lack of movement of TmRSV antigen and RNA into the leaves of peach trees under Pennsylvania field conditions is unexplained.

Hybridization was more efficient than ELBA in detecting TmRSV infection of nectarine trees when bark extracts were analyzed, but ELISA was more efficient when root extracts were analyzed. The reason for these differences is unknown.

The maximum ELISA efficiency for detecting TmRSV in nectarines (Table 1) of $71 \%$ is unsatisfactory for many certification and experimental purposes. Hybridization with a cRNA probe should improve the diagnostic efficiency in woody plants. Also, hybridization may be useful for confirming the etiology of diseases of other weedy plants with symptoms similar but not identical to PSP.

Detection of TmRSV by hybridization with ${ }^{32} \mathrm{P}$-labeled transcribed cRNA probes offers

Table 2. Comparison of the distribution of TmRSV in infected apple and nectarine trees as revealed by dot blot hybridization assay with ${ }^{32} \mathrm{P}$-labeled TmRSV cRNA probes. ${ }^{2}$

\begin{tabular}{ccccccccc}
\hline \hline & & \multicolumn{3}{c}{ Apple tissue } & & \multicolumn{3}{c}{ Nectarine tissue } \\
\cline { 2 - 5 } \cline { 3 - 8 } Tree & Infection & Leaf & Bark & Root & & Leaf & Bark & Root \\
\hline 1 & Yes & - & - & - & - & + & - \\
2 & Yes & + & - & - & - & + & - \\
3 & Yes & + & - & - & - & + & - \\
4 & Yes & - & - & + & - & + & - \\
5 & Yes & - & - & + & - & + & + \\
6 & No & - & - & - & - & - & - \\
\hline
\end{tabular}

${ }^{2}$ Nucleic acid extracts were from rootstock suckers of five 'Delicious'/MM.106 apple trees (numbered 1-5) with apple union necrosis and decline and from five nectarine trees (also numbered 1-5) with Prunus stem-pitting disease. The uninfected 'Delicious'/MM.106 apple and nectarine trees (both numbered 6) were from the Pennsylvania virus-indexed repository. Tissues were collected in the spring. A negative sign indicates lack of hybridization; a positive sign indicates hybridization.

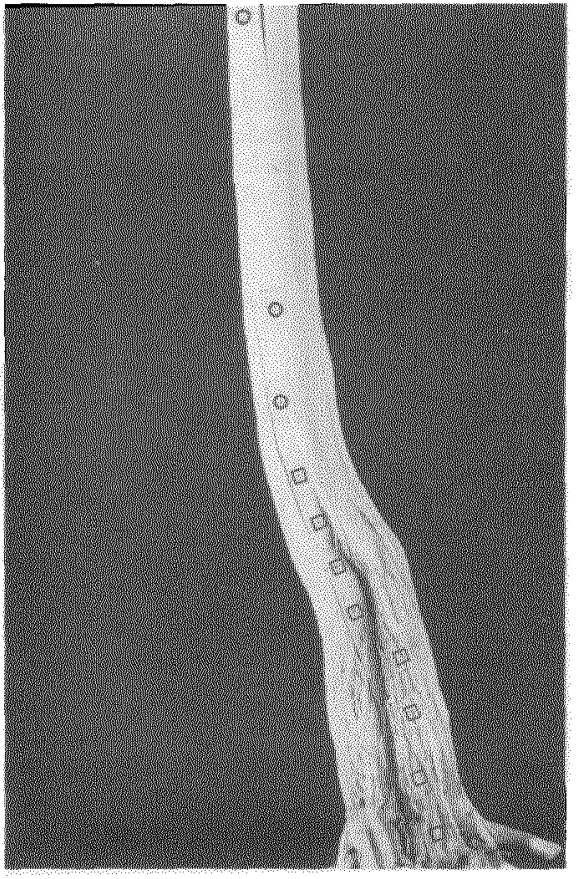

Fig. 1. Nectarine tree trunk with the Prunus stempitting disease. Squares indicate the location of bark in which TmRSV-RNA was detected by dot hybridization. Circles indicate the locations at which TmRSV RNA was not detected.

clear advantages over ELISA for epidemiological studies on orchard trees. Declining peach trees frequently show symptoms that are similar, but not identical, to classic PSP symptoms. Hybridization should be able to identify more clearly which trees are truly infected with TmRSV.

The effectiveness of hybridization to detect TmRSV in presymptomatic, infected nursery stock still needs to be determined because of its implications for certification and breeding programs.

\section{Literature Cited}

Bitterlin, M.W. and D. Gonsalves. 1988. Serological grouping of tomato ringspot virus isolates: Implications for diagnosis and crossprotection. Phytopathology 78:278-285.

Bitterlin, M. W., D. Gonsalves, and J. Cummins. 1984. Irregular distribution of tomato ringspot virus in apple trees. Plant Dis. 68:567-571.

Bitterlin, M. W., D. Gonsalves, and J.G. Barrat. 1988. Distribution of tomato ringspot virus in peach trees: implications for viral detection. Plant Dis. 72:59-63.

Clark, M.F. and A.N. Adams. 1977. Characteristics of the microplate method of enzyme-linked immunosorbent assay for the detection of plant viruses. J. Gen. Virol 34:475-483.

Gonsalves, D. 1981. Detection of tomato ringspot virus in grapevines: irregular distribution of virus. Proc. Mtg. Intl. Council for Viruses and Virus-Dis. Grapevines (ICVG) 7:95-106.

Hadidi, A. and C.A. Powell. 1991. Complementary DNA cloning and analysis of RNA 2 of a Prunus stem-pitting isolate of tomato ringspot virus. Molecular and Cellular Probes. (In press.)

Lister, R. M., W.R. Allen, D. Gonsalves, A.R. Gotlieb, C.A. Powell, and R.F. Stouffer. 1980. Detection of tomato ringspot virus in apple and 
peach by ELISA. Acta Phytopath. Acad. Sci. Hungary 15:47-55.

Mink, G. I., W.E. Howell, and P.R. Fridlund. 1985. Apple tip leaf antigens that cause spurious reactions with tomato ringspot virus antisera in enzyme-linked immunosorbent assay. Phytopathology 75:325-329.
Powell, C.A. 1984. Comparison of enzyme-linked immunosorbent assay procedures for detection of tomato ringspot virus in woody and herbaceous hosts. Plant Dis. 68:908-909.

Powell, C.A. 1987. Detection of three plant viruses by dot-immunobinding assay. Phytopathology 77:306-309.
Powell, C.A. 1990. Detection of tomato ringspot virus with monoclinal antibodies. Plant Dis. 74:904-907.

Powell, C.A. and M.A. Derr. 1983. An enzymelinked immunosorbent blocking assay for comparing closely related virus isolates. Phytopathology 73:660-664. 